\title{
Praca zarobkowa jako przesłanka utraty prawa do zasiłku chorobowego w orzecznictwie sądów powszechnych, Sądu Najwyższego oraz Trybunału Konstytucyjnego
}

1. Zgodnie z art. 67 ust. 1 obowiązującej Konstytucji Rzeczypospolitej Polskiej ${ }^{1}$ "obywatel ma prawo do zabezpieczenia społecznego w razie niezdolności do pracy ze względu na chorobę lub inwalidztwo oraz po osiągnięciu wieku emerytalnego. Zakres i formy zabezpieczenia społecznego określa ustawa". Z wyrażonej w art. 67 ust. 1 Konstytucji RP normy prawnej wynika gwarancja prawa do zabezpieczenia społecznego dla obywatela, który nie ma możliwości wykonywania pracy, a przez to zdobywania środków na zaspokajanie podstawowych potrzeb życiowych m.in. ze względu na takie rodzaje ryzyka socjalnego, jak inwalidztwo czy choroba. Przy czym rozróżnienie pomiędzy chorobą i inwalidztwem można wytłumaczyć celem przyznawanych świadczeń. O ile bowiem inwalidztwo rozumiane jest jako stan trwały i raczej nieodwracalny, o tyle w przypadku choroby mamy do czynienia ze stanami przejściowymi, przemijającymi ${ }^{2}$. Natomiast norma kompetencyjna, wynikająca z drugiego zdania art. 67 ust. 1, daje ustawodawcy zwykłemu bardzo szeroki zakres swobody w kształtowaniu tej formy przezorności, która obejmuje w zasadzie wszystkie kwestie związane z ryzykiem

${ }^{1}$ Konstytucja Rzeczypospolitej Polskiej z dnia 2 IV 1997 r. (Dz.U. Nr 78, poz. 483 ze zm.), dalej „Konstytucja RP”.

${ }^{2}$ K. Ślebzak, Komentarz do art. 67 Konstytucji, w: Konstytucja RP. Komentarz, t. 1, pod red. M. Safjana, L. Boska, Warszawa 2016, s. 1512. 
socjalnym ${ }^{3}$. W związku z powyższym uchwalona została m.in. Ustawa z dnia 13 października 1998 r. o systemie ubezpieczeń społecznych ${ }^{4}$. W myśl jej przepisów na system ubezpieczeń społecznych składają się cztery odrębne ubezpieczenia: emerytalne, rentowe, $\mathrm{w}$ razie choroby i macierzyństwa oraz wypadkowe. Ubezpieczenie $w$ razie choroby i macierzyństwa, zwane ubezpieczeniem chorobowym, jest związane z ryzykiem niezdolności do pracy wywołanej chorobą i ciążą. Przedmiotem ochrony w czasie trwania ubezpieczenia chorobowego jest utrata dochodów z powodu czasowej niezdolności do pracy, natomiast po ustaniu ubezpieczenia to zapewnienie środków utrzymania w czasie trwania spowodowanej stanem zdrowia przeszkody w poszukiwaniu nowego zatrudnienia ${ }^{5}$. W zależności od tytułu do ubezpieczenia chorobowego ma ono charakter obligatoryjny bądź fakultatywny. Pracownicy, członkowie rolniczych spółdzielni produkcyjnych i spółdzielni kółek rolniczych oraz osoby odbywające służbę zastępczą należą do grona ubezpieczonych objętych ubezpieczeniem chorobowym obowiązkowo (art. 11 ust. 1 ustawy o s.u.s.), pozostali zaś ubezpieczeni, w tym osoby prowadzące działalność pozarolnicza, mogą przystąpić dobrowolnie do ubezpieczenia chorobowego (art. 11 ust. 2 ustawy o s.u.s.). Reasumując, czasowa niezdolność do pracy, jako zdarzenie ubezpieczeniowe, przy spełnieniu przewidzianych prawem warunków otwiera drogę do świadczenia ${ }^{6}$.

Podstawowym świadczeniem związanym z ubezpieczeniem chorobowym i z wystąpieniem ryzyka niezdolności do pracy spowodowanego chorobą jest zasiłek chorobowy.

Tryb przyznawania zasiłku chorobowego we wcześniejszym stanie prawnym określała Ustawa z dnia 17 grudnia 1974 r. o świadczeniach pieniężnych z ubezpieczenia społecznego w razie choroby i macierzyństwa ${ }^{7}$, obecnie zaś, obowiązująca od dnia 1 września 1999 r., Ustawa

${ }^{3}$ Tak K. Ślebzak, Prawny charakter składek na ubezpieczenie społeczne, w: Ubezpieczenie społeczne - dawniej i dziś. W 80-lecie uchwalenia ustawy o ubezpieczeniu społecznym, Wrocław 2013, s. 113-114.

${ }^{4}$ Tekst jedn. Dz.U. 2017, poz. 1778, dalej „ustawa o s.u.s.”.

${ }^{5}$ I. Jędrasik-Jankowska, Niektóre regulacje prawne ubezpieczenia chorobowego, rentowego $i$ wypadkowego a konstytucyjna zasada równości i sprawiedliwości, „Annales Universitatis Mariae Curie-Skłodowska" 2015, nr 2, s. 83-84.

${ }^{6}$ A. Napiórkowska, Ryzyko w ubezpieczeniu społecznym, „Państwo i Prawo" 2012, nr 12, s. 71.

7 Tekst jedn. Dz.U. 1983 Nr 30, poz. 143 ze zm. 
z dnia 25 czerwca 1999 r. o świadczeniach pieniężnych z ubezpieczenia społecznego $\mathrm{w}$ razie choroby i macierzyństwa ${ }^{8}$.

W zarysie konstrukcja prawna zasiłku chorobowego jest następująca. Przysługuje on ubezpieczonemu, który stał się niezdolny do pracy z powodu choroby w czasie trwania ubezpieczenia chorobowego, po odpowiednim okresie wyczekiwania, który wynosi 30 dni - jeżeli ubezpieczony podlega obowiązkowo ubezpieczeniu chorobowemu (art. 4 ust. 1 pkt 1 u.z.) oraz $90 \mathrm{dni}$ w przypadku ubezpieczenia dobrowolnego (art. 4 ust. 1 pkt 2 u.z.). Zasiłek chorobowy przysługuje również osobie, która stała się niezdolna do pracy po ustaniu tytułu ubezpieczenia chorobowego, jeżeli niezdolność do pracy trwała bez przerwy co najmniej 30 dni i powstała: (1) nie później niż w ciągu 14 dni od ustania tytułu ubezpieczenia chorobowego; (2) nie później niż w ciągu 3 miesięcy od ustania tytułu ubezpieczenia chorobowego - w razie choroby zakaźnej, której okres wylęgania jest dłuższy niż 14 dni, lub innej choroby, której objawy chorobowe ujawniają się po okresie dłuższym niż 14 dni od początku choroby. Zasiłek chorobowy przysługuje przez okres trwania niezdolności do pracy z powodu choroby lub niemożności wykonywania pracy $\mathrm{z}$ powodu przebywania $\mathrm{w}$ szpitalu lub innym zakładzie leczniczym - nie dłużej jednak niż przez 182 dni, a jeżeli niezdolność do pracy została spowodowana gruźlicą lub występuje w trakcie ciąży nie dłużej niż przez 270 dni.

Ustawodawca określił katalog przyczyn wyłączających prawo do zasiłku chorobowego. Wynikają one m.in. z treści art. 13 i 17 ustawy zasiłkowej. Zgodnie z art. 13 ust. 1 u.z. świadczenie to nie przysługuje po ustaniu tytułu ubezpieczenia chorobowego, jeżeli osoba niezdolna do pracy: ma ustalone prawo do emerytury lub renty z tytułu niezdolności do pracy (pkt 1), kontynuuje działalność zarobkową lub podjęła działalność zarobkową stanowiącą tytuł do objęcia obowiązkowo lub dobrowolnie ubezpieczeniem chorobowym albo zapewniająca prawo do świadczeń za okres niezdolności do pracy z powodu choroby (pkt 2), nie nabyła prawa do zasiłku chorobowego z uwagi na brak okresu wyczekiwania (pkt 3), jest uprawniona do zasiłku dla bezrobotnych, zasiłku przedemerytalnego, świadczenia przedemerytalnego lub nauczycielskiego świadczenia kompensacyjnego (pkt 4), podlega obowiązkowo ubezpieczeniu społecznemu rolników (pkt 5). Nie przysługuje on również za okres niezdolności do pracy po ustaniu tytułu

\footnotetext{
${ }^{8}$ Tekst jedn. Dz.U. 2017, poz. 1368 ze zm., dalej „ustawa zasiłkowa” lub „u.z.”.
} 
ubezpieczenia chorobowego, jeżeli ubezpieczenie to ustało po wyczerpaniu prawa do zasiłku chorobowego (art. 13 ust. 2 u.z.). W regulacji art. 13 ust. 1 komentowanej ustawy zostały określone przesłanki negatywne, bowiem ustawodawca wskazał, że wystąienie choć jednej z tych przesłanek przesądza o tym, że prawo do zasiłku nie przysługuje ${ }^{9}$. Natomiast w art. 13 ust. 2 u.z. ustawodawca wskazał wprost, że analizowane świadczenie nie przysługuje za okres niezdolności do pracy po ustaniu tytułu ubezpieczenia chorobowego, jeżeli ubezpieczenie to ustało po wyczerpaniu prawa do zasiłku ${ }^{10}$.

Zgodnie natomiast $\mathrm{z}$ art. 17 ust. 1 ustawy zasiłkowej ubezpieczony wykonujący w okresie orzeczonej niezdolności pracę zarobkową lub wykorzystujący zwolnienie od pracy niezgodnie z jego celem traci prawo do zasiłku chorobowego za cały okres tego zwolnienia. Z treści art. 17 ustawy zasiłkowej wynikają zatem dwie przesłanki utraty prawa do zasiłku chorobowego. Pierwszą jest wykonywanie pracy zarobkowej w okresie niezdolności do pracy, drugą zaś wykorzystanie zwolnienia w sposób niezgodny z jego celem ${ }^{11}$. Przesłanki utraty prawa do zasiłku są niezależne od siebie i mają samoistny charakter. Pogląd ten na tle obecnie obowiązującej ustawy jest ugruntowany zarówno w piśmiennictwie, jak i w orzecznictwie ${ }^{12}$. Powyższe stanowisko zajął też Sąd Najwyższy (SN), potwierdzając, że „ubezpieczony traci prawo do zasiłku chorobowego (świadczenia rehabilitacyjnego) w przypadku wystąpienia jednej z dwóch niezależnych przesłanek [...], a więc wykonywania pracy zarobkowej w okresie orzeczonej niezdolności do pracy lub wykorzystywania zwolnienia od pracy w sposób niezgodny z celem tego zwolnienia"13. Pogląd ten zasługuje na aprobatę, gdyż łączne traktowanie obu przesłanek skutkowałoby sytuacją, w której

${ }^{9}$ E. Darmorost, Komentarz do art. 13 ustawy o świadczeniach pieniężnych z ubezpieczenia społecznego w razie choroby i macierzyństwa, LEX nr 198902.

${ }^{10}$ Ibidem.

${ }^{11}$ Zob. I. Jędrasik-Jankowska, Pozbawienie prawa do świadczeń z ubezpieczenia społecznego, „Praca i Zabezpieczenie Społeczne” 1986, nr 5-6, s. 31.

12 A. Rzetecka-Gil, Ustawa o świadczeniach pieniężnych z ubezpieczenia społecznego w razie choroby i macierzyństwa. Komentarz do art. 17 ustawy zasitkowej, LEX/el. 2017.

${ }^{13}$ Wyrok SN z 20 I 2005 r., sygn. I UK 154/04, bardzo istotny ze względu na to, że rozstrzyga dwie kwestie związane z interpretacją art. 17 u.z. Po pierwsze, wskazuje, że wynikające $z$ tego przepisu przesłanki utraty prawa do zasiłku należy traktować odrębnie. Po drugie, wyjaśnia, jak należy rozumieć pojęcie „pracy zarobkowej”, o czym będzie mowa w dalszej części artykułu. Zob. P. Prusinowski, Wykonywanie pracy zarobkowej jako przyczyna pozbawienia prawa do zasiłku chorobowego, „Z Zagadnień Zabezpieczenia Społecznego" 2011, nr 3, s. 27 i n. 
ubezpieczony nie traciłby prawa do zasiłku chorobowego, wykonując nieodpłatnie pracę, mimo że pogarszała stan zdrowia ${ }^{14}$.

2. W dalszej części rozważań analizie poddano pracę zarobkową jako jedną z przyczyn powodujących utratę prawa do zasiłku chorobowego. Ustawodawca, o czym była już mowa, posługuje się tą przesłanką w dwóch artykułach ustawy zasiłkowej, tj. w art. 13 i 17. Przede wszystkim należy stwierdzić, że art. 17 u.z. budzi, o czym mowa dalej, poważne wątpliwości interpretacyjne w odniesieniu do różnych stanów faktycznych. Taki stan rzeczy powoduje, że organy rentowe popełniają błędy, wydając decyzje, sądy zaś stosują ten przepis niejednolicie. Z kolei szczegółowa analiza orzecznictwa Sądu Najwyższego wyjaśnia, dlaczego ustawodawca przyjął taka, a nie inną konstrukcję art. 17 u.z.

Ustalając treść powyższych przepisów, należy określić ich zakres podmiotowy. Przepis art. 17 ust. 1 u.z. stanowi, że ubezpieczony wykonujący w okresie orzeczonej niezdolności pracę zarobkową traci prawo do zasiłku chorobowego za cały okres tego zwolnienia. Zgodnie zaś $\mathrm{z}$ art. 1 ust. 1 u.z. „ubezpieczonym” w rozumieniu ustawy jest osoba objęta ubezpieczeniem społecznym w razie choroby i macierzyństwa określonym w ustawie o systemie ubezpieczeń. Norma prawna zawarta w art. 17 ust. 1 u.z. skierowana jest zatem wyłącznie do osób niezdolnych do pracy w czasie, gdy są objęte ubezpieczeniem chorobowym ${ }^{15}$. Z kolei art. 13 ust. 1 pkt 2 u.z. odnosi się wyłącznie do osób, które utraciły tytuł do ubezpieczenia chorobowego, reguluje bowiem kwestię utraty zasiłku chorobowego po ustaniu tytułu do tego ubezpieczenia, chociaż dotyczy zarówno zasiłku chorobowego przyznanego w czasie trwania ubezpieczenia chorobowego, jak i z tytułu niezdolności do pracy powstałej po ustaniu tytułu do ubezpieczenia chorobowego. Kolejne trudności interpretacyjne rodzi sposób określenia okresu utraty zasiłku i w konsekwencji ustalenia wysokości nienależnie pobranego świadczenia, które winno być zwrócone. Przepis art. 17 ust. 1 u.z. stanowi, że ubezpieczony podejmujący pracę zarobkową w okresie orzeczonej niezdolności do pracy traci prawo do zasiłku chorobowego za cały okres tego zwolnienia. Nie ma wątpliwości, że ubezpieczony, legitymujący się niezdolnością do pracy ustaloną na podstawie jednego zaświadczenia lekarskiego, utraci prawo do zasiłku chorobowego za cały okres

${ }^{14}$ U. Jackowiak, Glosa do wyroku SN z dnia 20 stycznia 2005 r., II UK 154/04, LEX nr 175814.

${ }^{15}$ Por. wyrok SN z 13 VI 2013 r., sygn. I UK 19/13, LEX nr 1413492. 
ustalony tym zaświadczeniem. Problem pojawia się w przypadku, gdy ubezpieczony otrzymuje zasiłek chorobowy nieprzerwanie np. przez dwa miesiące, ale na podstawie zaświadczeń lekarskich wystawianych na następujące po sobie kolejne okresy. Zrodziło się więc pytanie, czy na pewno osoba, która podejmuje pracę zarobkową w takiej sytuacji, powinna utracić prawo tylko do zasiłku chorobowego orzeczonego zaświadczeniem lekarskim obejmującym okres, w którym nastąpiło podjęcie pracy zarobkowej, czy też za cały okres niezdolności do pracy. Wątpliwości rozwiał Sąd Najwyższy, orzekając, że utrata prawa do zasiłku chorobowego dotyczy tylko okresu objętego zaświadczeniem (zwolnieniem) lekarskim, w którym nastąpiło podjęcie pracy zarobkowej, a nie całego okresu zasiłkowego ${ }^{16}$. W uzasadnieniu rozstrzygnięcia SN wskazał, że "w sytuacji, gdy ubezpieczony przebywa na zwolnieniach lekarskich (legitymuje się czasową niezdolnością do pracy zarobkowej) na podstawie wydanych przez uprawnionego lekarza kilku zaświadczeń lekarskich, dotyczących kolejno następujących po sobie okresów, to każdy z nich (wskazany w poszczególnych zaświadczeniach lekarskich) podlega odrębnej ocenie z punktu widzenia utraty prawa do zasiłku chorobowego na podstawie art. 17 ust. 1 ustawy. Utrata prawa do zasiłku chorobowego dotyczy natomiast tylko tego z okresów objętych zaświadczeniem (zwolnieniem) lekarskim, w którym nastąpiło podjęcie pracy zarobkowej, a nie całego okresu zasiłkowego".

Natomiast odnośnie do regulacji wynikającej z art. 13 u.z. ustawodawca również nie określił, w jaki sposób należy ustalić okres utraty prawa do zasiłku. Konieczne jest więc posiłkowanie się orzecznictwem. Sąd Najwyższy stwierdził, że skoro z regulacji zawartej w art. 13 u.z. wynika, iż zasiłek chorobowy w ogóle nie przysługuje za okres po ustaniu tytułu ubezpieczenia chorobowego, czyli nie odnosi się do poszczególnych zwolnień, tak jak w art. 17 u.z., zatem kontynuowanie lub podjęcie działalności zarobkowej powoduje utratę świadczenia za cały okres tej działalności ${ }^{17}$.

Ustalając treść art. 17 u.z., należy także zwrócić uwagę na słowa „praca zarobkowa”, która stanowi przesłankę utraty prawa do zasiłku chorobowego. Ustawa zasiłkowa nie zawiera definicji tego pojęcia. Przez pracę zarobkową należy więc rozumieć wszelką pracę zarobkową wykonywaną na każdej podstawie prawnej albo bez takiej podstawy

16 Tak wyrok SN z 25 II 2008 r., sygn. I UK 249/07, LEX nr 500055; por. też wyrok SN z 2 VIII 2017 r., sygn. II UK 205/17, LEX nr 2365175.

17 Tak wyrok SN z 9 I 2012 r., sygn. I UK 212/11, LEX nr 1230277. 
$\left(\right.$ praca "na czarno") ${ }^{18}$. Pracą w rozumieniu komentowanego przepisu jest praca w potocznym tego słowa znaczeniu, w tym także wykonywanie różnych czynności na podstawie różnych stosunków prawnych, stosunku pracy, stosunków o charakterze cywilnoprawnym, a także prowadzenie własnej działalności gospodarczej, samozatrudnienie ${ }^{19}$.

Ponadto w orzecznictwie Sądu Najwyższego przeważa pogląd, że każda praca zarobkowa wykonywana w okresie zwolnienia lekarskiego powoduje utratę prawa do zasiłku chorobowego, chociażby wykonywanie pracy było zalecane i przyczyniało się do poprawy stanu zdrowia. W okresie korzystania ze zwolnienia lekarskiego pracownik może wykonywać pewne prace niepowodujące utraty prawa do zasiłku chorobowego pod warunkiem, że nie mają charakteru zarobkowego ${ }^{20}$. Pracą zarobkową jest wszelka aktywność ludzka, która zmierza do uzyskania zarobku, w tym pozarolnicza działalność gospodarcza ${ }^{21}$, wykonywanie czynności nadzorczych przez członka rady nadzorczej spółki akcyjnej ${ }^{22}$, odpłatne wykonywanie przez radcę prawnego w czasie zwolnienia lekarskiego czynności zawodowych ${ }^{23}$.

W przypadku osób prowadzących działalność pozarolnicza, w tym działalność gospodarcza, pracą będzie wykonywanie konkretnych czynności związanych wprost $\mathrm{z}$ działalnością gospodarczą, w tym nadzór nad zatrudnionymi pracownikami, obsługa klientów, przyjmowanie i wydawanie materiałów ${ }^{24}$. Tylko „czynności formalnoprawne podejmowane w okresie niezdolności do pracy przez osobę prowadzącą działalność gospodarczą w związku z posiadanym przez nią statusem pracodawcy

${ }^{18}$ Z. Kluszczyńska, Świadczenia pieniężne w razie choroby i macierzyństwa, w: System Ubezpieczeń Społecznych. Zagadnienia podstawowe, pod red. G. Szpor, wyd. 3, Warszawa 2006, s. 89.

${ }^{19}$ Tak SN w wyrokach: z 20 I 2005 r., sygn. I UK 154/04, LEX nr 150101; z 9 X 2006 r., sygn. II UK 44/06, LEX nr 309449; z 15 VI 2007 r., sygn. II UK 223/06, LEX nr 422751; z 5 VI 2008 r., sygn. III UK 11/08, LEX nr 528605.

${ }^{20}$ Wyrok SN z 31 V 1985 r., sygn. II URN 75/85, LEX nr 12900, dotyczy interpretacji art. 18 ust. 1 Ustawy z dnia 17 XII 1974 r. o świadczeniach pieniężnych z ubezpieczenia społecznego w razie choroby i macierzyństwa (Dz.U. 1983 Nr 30, poz. 143 ze zm.), jednak pogląd w nim prezentowany stanowi także podstawę rozstrzygnięć zapadających pod rządami obowiązującej ustawy zasiłkowej; por. wyrok Sądu Okręgowego (SO) w Łodzi z 8 VIII 2014 r., sygn. VII Ua 70/14, http://orzeczenia.ms.gov.pl/details/\$N/152510000003521_VII_Ua_000070_2014_Uz_2014-06-24_001 (dostęp: 28 II 2018).

${ }^{21}$ Wyrok SN z 5 IV 2005 r., sygn. I UK 370/04, LEX nr 157330.

22 Wyrok SN z 20 I 2005 r., sygn. I UK 154/04, LEX nr 150101.

${ }^{23}$ Wyrok SN z 14 XII 2005 r., sygn. III UK 120/05, LEX nr 201295.

${ }^{24}$ Wyrok SN z 17 I 2002 r., sygn. II UKN 710/00, LEX nr 56864. 
nie są pracą zarobkową"25, gdyż „w przeciwnym razie choroba pracodawcy oznaczałaby konieczność likwidacji zakładu pracy, zwalniania pracowników z pierwszym dniem jego choroby i obowiązek wypłacania im należności za okres wypowiedzenia, a po odzyskaniu zdolności do pracy, ponowne poszukiwanie i zatrudnianie pracowników"26. Poza tym do utraty prawa do zasiłku chorobowego nie dochodzi tylko w przypadku aktywności zmierzającej do osiągnięcia zarobku w czasie pobierania tego zasiłku, gdy ma ona charakter incydentalny i wymuszony okolicznościami ${ }^{27}$ lub jest uzasadniona potrzebą środowiskowa, społeczną czy publiczną ${ }^{28}$, taką jak udział $w$ akcjach ratowniczych ochotniczej straży pożarnej ${ }^{29}$ czy udział radnego w posiedzeniach rady gminy ${ }^{30}$.

Druga przesłanka, która powoduje wstrzymanie prawa do zasiłku chorobowego, to podjęcie takiej aktywności, która co prawda, nie ma charakteru zarobkowego, ale może spowodować zakłócenie procesu leczenia i przywrócenia zdolności do pracy.

Wykonywanie czynności mogących przedłużyć okres niezdolności do pracy zawsze stanowi wykorzystywanie zwolnienia niezgodnie z jego celem, którym jest odzyskanie przez ubezpieczonego zdolności do pracy. W jego osiągnięciu przeszkodą może być zarówno wykonywanie pracy zarobkowej (co przesądził ustawodawca), jak i inne zachowania ubezpieczonego utrudniające proces leczenia i rekonwalescencję ${ }^{31}$.

Zgodnie z utrwalonym orzecznictwem sądowym najistotniejszą funkcją zasiłku chorobowego jest kompensata utraconego przez ubezpieczonego dochodu wskutek wystąpienia u niego czasowej, przejściowej niezdolności do zarobkowania ${ }^{32}$. Celem tym nie jest natomiast uzyskanie dodatkowej korzyści poza wynagrodzeniem, dlatego zasiłek chorobowy wypłacany jest nie oprócz, ale zamiast wynagrodzenia ${ }^{33}$.

${ }^{25}$ Wyrok SN z 6 V 2009 r., sygn. II UK 359/08, LEX nr 687081.

${ }^{26}$ Wyrok SN z 7 X 2003 r., sygn. II UK 76/03, LEX nr 109913; por. wyrok SN z 4 IV 2012 r., sygn. II UK 186/11, LEX nr 1216851.

${ }^{27}$ Wyrok SN z 9 X 2006 r., sygn. II UK 44/06, LEX nr 309449; por. wyrok SN z 15 VI 2007 r., sygn. II UK 223/06, LEX nr 422751.

${ }^{28}$ Wyrok SN z 5 IV 2016 r., sygn. II UK 171/15, LEX nr 2368283.

${ }^{29}$ Wyrok SN z 14 V 2009 r., sygn. I UK 351/08, LEX nr 515410.

${ }^{30}$ Postanowienie SN z 25 I 2013 r., sygn. I UK 571/12, LEX nr 1555269.

${ }^{31}$ Wyrok SN z 25 IV 2013 r., sygn. I UK 606/12, LEX nr 1391152.

32 Por. wyrok SO w Elblągu z 31 X 2014 r., sygn. IV Ua 59/14, http://orzeczenia.ms. gov.pl/details/\$N/151010000002021_IV_Ua_000059_2014_Uz_2014-10-31_001; wyrok SO w Łodzi z 19 IX 2016 r., sygn. VIII Ua 34/16, http://orzeczenia.ms.gov.pl/details/\$N/152510000004021_VIII_Ua_000034_2016_Uz_2016-08-09_001 (dostęp: 1 III 2018).

33 A. Rzetecka-Gil, op. cit. 
3. Na tym tle problemy interpretacyjne rodzi wyrok Trybunału Konstytucyjnego (TK) z 25 lutego 2014 r. ${ }^{34}$ Trybunał przyjął, że art. 17 ust. 1 u.z. "W zakresie, w jakim stanowi podstawę utraty prawa do zasiłku chorobowego ubezpieczonego, który w okresie orzeczonej niezdolności do pracy wykonywał pracę zarobkową, uzyskując wynagrodzenie przekraczające minimalną wysokość wynagrodzenia za pracę, jest zgodny z art. 67 ust. 1 w związku z art. 64 ust. 1 i 2, art. 31 ust. 3 oraz art. 2 Konstytucji Rzeczypospolitej Polskiej". Wyrok ten został wydany na tle następującego stanu faktycznego. W okresie od 15 października 2007 r. do 31 marca 2008 r. ubezpieczona była nieprzerwanie niezdolna do pracy z powodu choroby i za powyższy okres otrzymała zasiłek chorobowy. Jednocześnie w trakcie orzeczonej niezdolności do pracy świadczyła pracę na podstawie umowy zlecenia u innego pracodawcy, otrzymując wynagrodzenie. Trybunał stwierdził, że ustawodawca, uzależniając przyznanie prawa do zasiłku chorobowego zarówno od niezdolności do pracy, jak i od braku posiadania przez ubezpieczonego innych możliwości zarobkowania, nie naruszył art. 67 ust. 1 Konstytucji RP. Podkreślił jednocześnie, że istotą gwarancji przewidzianych w tym przepisie ustawy zasadniczej jest przyznanie świadczeń obywatelom niezdolnym do pracy, a przez to niemającym możliwości samodzielnego zarobkowania. Charakter tego świadczenia sprowadza się do zapewnienia ubezpieczonym zastępczego źródła dochodu przeznaczonego na utrzymanie przynajmniej na poziomie minimum życiowego. Jednocześnie nie chodzi o zapewnienie świadczenia, które wyrówna utracony zarobek. Ubezpieczony, który uzyskuje zarobek, wykonując pracę, traci prawo do zasiłku chorobowego, który jest zastępczym źródłem dochodu ${ }^{35}$.

${ }^{34}$ Wyrok TK z 25 II 2014 r., sygn. SK 18/13, LEX nr 1430363.

${ }^{35}$ W nauce prawa można spotkać pogląd, w myśl którego „Zwrot «praca zarobkowa» odznacza się wieloznacznością. Niedopuszczalne wydaje się twierdzenie, że każda aktywność przynosząca dochód stanowi pracę zarobkową lub każda praca, także nieprzynosząca bieżącego dochodu, jest pracą zarobkową w rozumieniu art. 17 ust. 1 u.ś.p.u.s. Interpretując pojęcie pracy zarobkowej przez pryzmat celu tej pracy, można wyprowadzić dwojaki tok myślenia. Cel ten może bowiem odnosić się do minimalnego wynagrodzenia za pracę albo do charakteru wykonywanych działań bez względu na wysokość osiągniętego dochodu. Z pierwszym poglądem koresponduje przywoływany wyrok TK w sprawie SK 18/13, w którym (w uproszczeniu) wykonywanie pracy zarobkowej utożsamiane zostaje z osiąganiem dochodu w wysokości wyższej niż minimalne wynagrodzenie za pracę" (K. Ryś, Wybrane problemy ubezpieczenia społecznego z tytułu niezdolności do pracy z powodu choroby, „Ubezpieczenia Społeczne. Teoria i Praktyka” 2017, nr 3, s. 87). 
W ocenie Trybunału Konstytucyjnego ustawodawca może - pozostając w granicach art. 67 ust. 1 Konstytucji RP - uzależnić prawo do zasiłku chorobowego od tego, czy potencjalny świadczeniobiorca, pozostając na zwolnieniu lekarskim, nie podejmował w ogóle jakiejkolwiek pracy zarobkowej. Dotyczy to także tych sytuacji, w których praca ta miałaby również znaczenie terapeutyczne, wspomagając proces leczenia. Ustawodawca może zatem - pozostając w granicach swobody wyznaczonej w art. 67 ust. 1 Konstytucji RP - wyznaczyć przesłanki prawa do zasiłku chorobowego zarówno w taki sposób, jaki wynika obecnie z art. 17 ust. 1 u.z. Mógłby je zmodyfikować, uwzględniając szczególny cel pracy zarobkowej realizowanej przez osoby pozostające na zwolnieniu lekarskim. Brak wprowadzenia takiej regulacji nie oznacza jednak naruszenia istoty art. 67 ust. 1 Konstytucji RP ${ }^{36}$.

Konfrontując treść powyższego rozstrzygnięcia z literalnym brzmieniem art. u.z., należy zauważyć, że Trybunał Konstytucyjny podjął się modyfikacji jego treści. Ustalił, że „praca zarobkowa” jako przesłanka utraty prawa do zasiłku chorobowego powinna być interpretowana z uwzględnieniem wysokości wynagrodzenia za pracę uzyskanego w czasie zwolnienia lekarskiego. Uprawnione bowiem wydaje się rozumowanie a contrario, które prowadzi do wniosku, że art. 17 ust. 1 u.z. w zakresie, w jakim stanowi podstawę utraty prawa do zasiłku chorobowego ubezpieczonego, który w okresie orzeczonej niezdolności do pracy wykonywał pracę zarobkowa, uzyskując wynagrodzenie nieprzekraczające minimalnej wysokości wynagrodzenia za pracę, jest niezgodny z Konstytucją RP.

I jakkolwiek Trybunał Konstytucyjny podkreślił odsyłający charakter art. 67 ust. 1 Konstytucji RP, który przekazuje ustawodawcy kompetencje do określenia zakresu i form zabezpieczenia chorobowego, to dokonał

${ }^{36}$ Sejm, oprócz wniosku o umorzenie postępowania, przedstawił argumenty przemawiające za zgodnością zaskarżonego przepisu. Zdaniem Sejmu ubezpieczony ma bowiem zapewnioną możliwość oceny swojej sytuacji materialnej i uwzględniając najkorzystniejsze dla siebie rozwiązania, może podjąć najlepszą w określonych warunkach faktycznych oraz prawnych decyzję, czy pobierać zasiłek chorobowy, czy też wykonywać pracę zarobkową. W tych warunkach jednostka zachowuje także możliwość kontynuowania nawet pracy zarobkowej w celach terapeutycznych pod warunkiem rezygnacji z zasiłku. Pełne uprawnienie do zasiłku chorobowego zachowuje z kolei pod warunkiem rezygnacji z pracy zarobkowej. W żadnym przypadku zaskarżony przepis nie sprzeciwia się, jak twierdzi skarżąca, pracy w celach terapeutycznych. Przywołane stanowisko Sejmu dostępne jest na stronie internetowej Trybunału Konstytucyjnego, http://ipo.trybunal. gov.pl/ipo/Sprawa? \&pokaz=dokumenty\&sygnatura=SK\%2018/13 (dostęp: 12 II 2018). 
ingerencji w te kompetencje. Ustanowił bowiem normę prawna, która nie ma oparcia w literalnym brzmieniu art. 17 u.z., w myśl której „praca zarobkowa" wykonywana w okresie orzeczonej niezdolności, przynosząca wynagrodzenie przekraczające minimalną wysokość, nie stanowi podstawy utraty prawa do zasiłku. Trybunał orzekł wbrew - jak sam podkreślił - dominującemu w orzecznictwie podejściu, przypisującemu zarobkowy charakter każdej działalności przynoszącej jakikolwiek dochód. Jednocześnie z treści rozstrzygnięcia wynika, że nie ma także znaczenia, czy praca miała sporadyczny, incydentalny i wymuszony okolicznościami charakter, czy też miała cechy regularnego zajęcia. Istota problemu sprowadzona została jedynie do wysokości uzyskiwanego wynagrodzenia, gdyż utożsamiono wykonywanie pracy zarobkowej z osiąganiem dochodu w wysokości wyższej niż minimalne wynagrodzenie za pracę ${ }^{37}$.

4. Taka wykładnia przepisu art. 17 ust. 1 u.z. nie znalazła i nie znajduje odzwierciedlenia oraz aprobaty w orzecznictwie sądów powszechnych. Tylko nieliczne sądy powołują się na powyższy wyrok i wskazują, że ze względu na treść jego sentencji „a contrario należałoby przyjąć, iż uzyskiwanie wynagrodzenia w wysokości poniżej minimalnej wysokości wynagrodzenia za pracę $\mathrm{w}$ okresie orzeczonej niezdolności do pracy nie stanowi pracy zarobkowej i taka interpretacja przepisu art. 17 cyt. ustawy wydaje się być zgodna z zasadą sprawiedliwości społecznej"38. Na marginesie warto dodać, że sąd powołujący się na wyrok TK ustalił, że co prawda, odwołująca się uzyskała wynagrodzenie niższe od minimalnego, jednak zasiłek chorobowy jest świadczeniem nienależnie pobranym ze względu na drugą przesłankę utraty prawa do tego zasiłku, tj. wykorzystywanie zwolnienia od pracy w sposób niezgodny z celem tego zwolnienia. Z kolei w sprawie zawisłej przed Sądem Rejonowym w Olsztynie wysokość osiągniętego dochodu była dużo niższa niż najniższe wynagrodzenie i była czynnikiem decydującym o przyznaniu świadczenia ${ }^{39}$. W innej sprawie, w której sąd powszechny odwołał się

\footnotetext{
${ }^{37}$ R. Babińska-Górecka, Wykonywanie pracy zarobkowej jako przesłanka utraty prawa do zasitku chorobowego (uwagi na tle art. 17 ust. 1 ustawy chorobowej), "Z zagadnień Zabezpieczenia Społecznego" 2014, nr 6, s. 7.

${ }^{38}$ Wyrok Sądu Rejonowego (SR) w Poznaniu z 15 III 2017 r., sygn. VI U 3393/15, http://orzeczenia.ms.gov.pl/details/\$N/153510300003021_VI_U_003393_2015_ Uz_2017-04-12_001 (dostęp: 2 III 2018).

${ }^{39}$ Wyrok SR w Olsztynie z 18 X 2017 r., sygn. IV U 66/17, http://orzeczenia.ms.gov. pl/content/\$N/150515250002021_IV_U_000066_2017_Uz_2017-11-06_001 (dostęp: 2 III 2018).
} 
do sentencji analizowanego wyroku Trybunału Konstytucyjnego, o rozstrzygnięciu zadecydowała nie tylko wysokość zarobku, ale także fakt, że czynności wykonywane przez skarżącą nie były sporadyczne, lecz powtarzalne każdego miesiąca ${ }^{40}$.

Analiza orzecznictwa wskazuje, że przywołany wyrok TK pozostaje irrelewantny w sprawach dotyczących utraty zasiłku chorobowego. Sądy stoją bowiem na stanowisku, że "art. 17 ustawy nie przewiduje szczególnych przypadków zezwalających na wypłatę zasiłków chorobowych, mimo świadczenia pracy zarobkowej w okresie zwolnienia lekarskiego. Przepis ten jest jednoznaczny, a zatem każda praca zarobkowa wykonywana w okresie zwolnienia lekarskiego powoduje utratę prawa do zasiłku chorobowego [... $]^{\prime 41}$ i nieistotne jest, że w efekcie podejmowanych działań żaden dochód czy zysk nie został osiągnięty ${ }^{42}$. Nie ma też znaczenia, czy "wykonywanie pracy było zalecane i przyczyniało się do poprawy stanu zdrowia w okresie korzystania ze zwolnienia lekarskiego. W okresie korzystania ze zwolnienia lekarskiego pracownik może wykonywać prace niepowodujące utraty prawa do zasiłku chorobowego, pod warunkiem, że prace te nie mają charakteru zarobkowego" ${ }^{\prime \prime 3}$. Okoliczność, że „zarobek [...] nie przekraczał wysokości minimalnego wynagrodzenia", nie ma znaczenia dla zakresu stosowania art. 17 u.z. ${ }^{44}$ Analogiczne stanowisko prezentuje Sąd Okręgowy w Koninie ${ }^{45}$.

${ }^{40}$ Wyrok SR dla Warszawy Pragi-Południe w Warszawie z 17 III 2016 r., sygn. VI U 552/14, http://orzeczenia.ms.gov.pl/content/\$N/154510200003021_VI_U_000552_ 2014_Uz_2016-03-17_001 (dostęp: 2 III 2018).

${ }^{41}$ Wyrok SO w Łodzi z 8 VII 2014 r., sygn. VII Ua 70/14, http://orzeczenia.ms.gov. pl/content/\$N/152510000003521_VII_Ua_000070_2014_Uz_2014-06-24_001 (dostęp: 2 III 2018); por. wyrok SO w Łodzi z 17 VI 2016 r., sygn. VII Ua 64/16, http://orzeczenia. ms.gov.pl/content/\$N/152510000003521_VII_Ua_000064_2016_Uz_2016-06-17_001 (dostęp: 2 III 2018); wyrok SO w Łodzi z 27 VII 2016 r., sygn. VIII Ua 19/16, http://orzeczenia.ms.gov.pl/content/\$N/152510000004021_VIII_Ua_000019_2016_Uz_2016-0712_001 (dostęp: 2 III 2018); wyrok SO w Łodzi z 19 X 2016 r., sygn. VIII Ua 25/16, http:// orzeczenia.ms.gov.pl/content/\$N/152510000004021_VIII_Ua_000025_2016_Uz_201610-19_001 (dostęp: 2 III 2018).

${ }^{42}$ Tak wyrok SO w Łodzi z 30 V 2016 r., sygn. VII Ua 41/16, http://orzeczenia. ms.gov.pl/content/\$N/152510000003521_VII_Ua_000041_2016_Uz_2016-05-30_001 (dostęp: 2 III 2018).

${ }^{43}$ Wyrok SO w Olsztynie z 15 XII 2017 r., sygn. IV Ua 73/17, http://orzeczenia. ms.gov.pl/content/\$N/150515000002015_IV_Ua_000073_2017_Uz_2017-12-15_002 (dostęp: 3 III 2018).

${ }^{44}$ Ibidem.

${ }^{45}$ Zgodnie z wyrokiem SO w Koninie z 29 V 2014 r., sygn. III Ua 9/14, ubezpieczona utraciła prawo do zasiłku chorobowego, gdyż w czasie zwolnienia lekarskiego 
Ponadto lektura orzeczeń sądów powszechnych zapadłych w sprawach utraty prawa do zasiłku wskazuje, że podstawowym drogowskazem w interpretowaniu art. 17 ust. 1 u.z. i definiowaniu użytego w nim zwrotu "praca zarobkowa” jest orzecznictwo Sądu Najwyższego, dla którego „pracą zarobkowa, której wykonywanie w okresie orzeczonej niezdolności do pracy powoduje utratę prawa do zasiłku chorobowego, jest każda aktywność ludzka zmierzająca do osiągnięcia zarobku [...], choćby nawet polegająca na czynnościach nieobciążających w istotny sposób organizmu ubezpieczonego i zarazem pracownika pozostającego na zwolnieniu lekarskim" ${ }^{\prime 4}$.

5. Reasumując, po pierwsze, ze zrekonstruowanych wypowiedzi sądów wynika, że pojęcie "praca zarobkowa” oznacza taką aktywność ubezpieczonego, która ma na celu osiągnięcie zarobku. Nieistotny z punktu widzenia prawa do zasiłku jest tytuł prawny, na podstawie którego osiągany jest zarobek oraz wymiar czasu pracy. Nie ma także znaczenia, czy wykonywana praca ma wpływ na stan zdrowia ubezpieczonego. Po drugie, organy rentowe oraz sądy nie badają wysokości osiągniętego dochodu, gdyż w świetle literalnego brzmienia art. 17 u.z. wysokość dochodu nie jest istotna. Dominuje wręcz pogląd, że nie ma żadnego znaczenia, czy wskutek pracy został osiągnięty jakikolwiek zarobek, jeżeli celem tej pracy było osiągnięcie przychodu. Po trzecie, inne stanowisko zają Trybunał Konstytucyjny, wydając wyrok interpretacyjny w sprawie SK 18/13 i dodając do art. 17 u.z. kryterium dochodowe. Zgodnie z wyrokiem TK prawo do zasiłku powinien tracić ubezpieczony uzyskujący zarobek w wysokości przekraczającej minimalne wynagrodzenie. Po czwarte, wyrok Trybunału jest, jak się wydaje, irrelewantny w sprawach o zasiłek chorobowy, ponieważ sądy nie znajdują w treści art. 17 u.z.

kontynuowała zatrudnienie u innego pracodawcy, u którego z tytułu umowy o pracę na 1/6 etatu otrzymywała wynagrodzenie w wysokości 140 zł miesięcznie, http://orzeczenia.ms.gov.pl/content/\$N/153505000001521_III_Ua_000009_2014_Uz_2014-05-29_001 (dostęp: 3 III 2018).

${ }^{46}$ Por. wyrok SO w Elblągu z 17 IV 2015 r., sygn. IV Ua 14/15, http://orzeczenia. ms.gov.pl/content/\$N/151010000002021_IV_Ua_000014_2015_Uz_2015-04-17_001 (dostęp: 3 III 2018); wyrok SO w Siedlcach z 18 VI 2015 r., sygn. IV Ua 3/15, http://orzeczenia.ms.gov.pl/content/\$N/153015000002021_IV_Ua_000003_2015_Uz_2015-06-18_001 (dostęp: 3 III 2018); wyrok SO w Łodzi z 18 II 2016 r., sygn. VII Ua 148/15, http://orzeczenia.ms.gov.pl/content/\$N/152510000003521_VII_Ua_000148_2015_Uz_2016-0218_001 (dostęp: 3 III 2018); wyrok SO w Koninie z 6 IX 2016 r., sygn. III Ua 18/16, http:// orzeczenia.ms.gov.pl/content/\$N/153505000001521_III_Ua_000018_2016_Uz_201609-06_001 (dostęp: 3 III 2018). 
"kryterium dochodowego" i nadal odwołują się do wypracowanej przez SN linii orzeczniczej. Tylko niektóre sądy dostrzegają treść wyroku TK i oceniają "pracę zarobkową" przez pryzmat osiągniętego dochodu. Po piąte, wyrok Trybunału nie spełnił swojej interpretacyjnej funkcji. Prawdopodobna przyczyna takiego stanu rzeczy jest następująca. Artykuł 17 u.z. budził wątpliwości interpretacyjne od początku obowiązywania ustawy zasiłkowej (tj. od 1 września 1999 r.). Jednak przez wiele lat stosowania utrwalił się już określony sposób rozumienia tego przepisu, ukształtowany głównie przez bogate orzecznictwo Sądu Najwyższego. Wykładnia art. 17 u.z. ustalona przez TK nie koresponduje z treścią tego przepisu ustaloną $\mathrm{w}$ drodze utrwalonego orzecznictwa SN. Warto dodać, że TK w uzasadnieniu przywoływanego wyroku nie wykazał w sposób jednoznaczny, na czym miałaby polegać niekonstytucyjność art. 17 u.z. $\mathrm{w}$ dotychczas stosowanym i utrwalonym znaczeniu. 